\title{
ARTICLE REVIEW OF THE CRITICAL AND EMPIRICAL RESEARCH IN ISLAMIC ECONOMICS
}

\author{
Ibrahim Foughali ${ }^{1}$ \\ Brahim Achour ${ }^{2}$ \\ Liya Ur Rahman Liyakath Alikhan ${ }^{3}$ \\ Nur Jamaludin ${ }^{4}$
}

1,2,3 International Islamic University Malaysia (IIUM)

${ }^{4}$ Sekolah Tinggi Ekonomi Syariah Islamic Village Tangerang

Email: ibrahimfoughali@hotmail.com, hamoubra@yahoo.com, liyaurrahman@yahoo.com, nurjamaludin@gmail.com

\begin{abstract}
This article depicts the nature scope and methodology of reconstruction of Islamic economics as well as it speaks about possibilities on theoretical and empirical research in this field. The article also intends to revel needy of reconstruction of Islamic economics, and its role in early stage and contemporary period and how it would be in future. Islamic economics through the shade of Quran and Sunnah clearly mandate about allocation of resources, goods and services as well as distribution of output, input and wealth in an economy. It is also giving the solution for the problems such as financial crises, poverty, inflation, economic inequalities and unemployment. In addition, methodologically, description of the ground realities and prescription of solutions for economic issues are concern of Islamic economics, whereas, field of fiqh plays massive role in developing of Islamic economics. Theoretically, this article discusses about Islamic economics theory and its advantages, this includes Islamic economic system, Sharia based transaction matrix, institutional matters, etc. on the empirical side, there are some points affiliated with data and empirical works are discussed.
\end{abstract}

\section{INTRODUCTION}

In the last two decades, Islamic banking and finance becomes well-known field in both western and eastern, when capitalism and socialism felt their weakness and fail to flourish the world economic systems. They now turn into the Islamic economic and its implementation. Especially, without any hesitation non-muslims also have been studying this subject. In addition to this recent arab spring in the Islamic countries indicate that the Islam is the way of life in the respective countries. This is because contemporary prolific scholars speaking about reconstruction of Islamic economics. Whereas, last four decades, considerable research of islamization of economics have been conducting by scholars, and where scholars started to speak islamization of economics.

In a nutshell, although world is gearing up to find the solution for economic crisis, poverty, unemployment, inequality and inflation, Islamic economics offers a new paradigm for blending concern about economic efficiency and economic stability with distributive justice. Throughout the last four decades, some important research efforts are done in the Islamic economics field. There are literatures, those are giving the valuable solution as alternative as capitalism and socialism. For instance, role of zakat, voluntary sector, Nature of riba, riba free financial intermediation and etc.

This paper briefly discuss about the needy of reconstruction of Islamic economics. Therefore this paper consist five chapters, where chapter two discuss about islamization of economics and how it would be implemented here, mainly contemporary economic system mixed with westerns ideologies; In normative frame work, western ideology has a certain view on man's behavior as an object in economic studies; whereas, Islam on the other hand view as human being and their relationship to other human beings and their nature also differ from western way. As well this chapter speaks about Islamic alternatives to overcome the circumstance of individual, ummah and humanity at large. In chapter three depicts prospects of methodology of Islamic economics and its models, here figh plays massive role in build up the Islamic economic instrument.

Also chapter four discuss about theoretical research on Islamic economics here scholars come out and try to elaborate new theories such as transaction norms, market function and structure. 


\section{Review Of Theoretical And Empirical Research In Islamic Economics}

Finally, in chapter five discusses about empirical side of Islamic economic where how it came across the history through last fourteen centuries, how it contributed in the respective societies, and finally discuss on the main purpose of this empirical research.

\section{Islamization of Economics, how to do?}

After the author simply explains in the introduction about the last decade of the $20^{\text {th }}$ century as the decade of change where the socialism in running toward collapse and also he mentions how the world today is seeking many solutions to solve problems of financial crises, poverty, inequality, unemployment, inflation and other economic problems since the capitalism also facing many problem and causes many crises. Moslem scholars in over the world, firms, government show the commitment to islamize the economic life such as: in Pakistan, Sudan, Iran and Malaysia and other countries. To support that, scholars, academicians have conducted a lot of considerable research in the area of Islamic economics.

The most important issue has been introduced in this part is what that is conveyed by Zarqa (2003) that based on his observation that mainstream economics rests on values judgments underlying the capitalistic paradigm and it is contrary with the Qur'an and the Sunnah. The distinct brings an implication to insert the set of value judgments of the sharia become foundations for a distinct discipline, namely Islamic economics. A methodological implication of his argument is this one may start with economics as it is, cleanse it of questionable elements, bring in the Islamic input and work out Islamic economic models and solutions. This is the Islamization of economics approach that greatly influenced the research effort during the last 40 years.

From the above statement we conclude that Zarqa as is quoted by Tahir (2017) in this paper offers the Islamization of economics through his 2 approaches, firstly we analyze the existing economics which one the part is compatible in Islamic view and which on incompatible. After ensuring those, Zarqa suggests to cleanse the elements in existing economics that contravenes the Islamic values by inserting Islamic teaching to the new economics. Secondly, we run the new model as called Islamic economics to solve the problems.

To comment or answer the existing model, Tahir invites us to make a clear definition through providing various definition from other Islamic economists. If we summarize, there are several important points, as follow:

- Islamic economics is branch of knowledge that aims to obtain human falah - successful people in this world and here after-- and prevent injustice achieved by organizing the resources of earth on the basis of cooperation and participation.

- The one important thing in Islamic economics is to provide satisfaction to human beings and enable them to perform their obligations to Allah and the society

- Islamic economics is a social science which studies the economic problems of a people imbued with the values of Islam based on the Qur'an and the Sunnah as well as by reason and experience.

- To attain the above aims, we should allocate and distribute the scarce resources in conformity with Islamic teachings without unduly curbing individual freedom or creating continued macroeconomic and ecological balances.

The clear definition according to Tahir, it is important in order to make we understand about the nature of Islamic economics and we can make a rational meaning about that as well as we can distinguish vis-a-vis to other economics system. Therefore, based on the above definition, we argue that Islamization of economics is not just throw whatever we look as something miss or wrong in Islamic perspective and put the Islamic value in this wrong to correct become more Islamic but more than that we should build the conception of the Islamic Economic from own meaning based on the sources of Islamic teaching ( $\mathrm{Al}$ quran and As-sunnah).

In this area we support the author Tahir (2017) who has laid down the main pillars for the Islamic Economics, namely : (i) belief in Allah SWT, (ii) belief in the life-hereafter, and (iii) belief in the Prophethood of Muhammad (pbuh). If we well know about these three pillars, it can guide us to reflect what the real of Islamic Economics is. A correct understanding of these fundamental ideas brings us toward a true vision of Islamic economics. The correct understanding about three elements above will derive a true Islamic world view. In the language of Wan Daud (1997), Islamic world view is something 


\section{Review Of Theoretical And Empirical Research In Islamic Economics}

very important because it is a central or core concept which pervades all aspects of life. These beliefs bring implication that in Islam there is not dichotomy and separation of religion from the other aspects such economy.

Similar with the Author Siddiqi as quoted by Haneef (1997), elaborates that there are three components of Islamic economics. The first component is Islamic worldview and vision relating to economics. It is a normative framework of economics. The second component is the analysis of actual human behavior in the different areas that make up economics (positive economics). This area discusses about 'what is' of economic behavior compared to the 'what should be' of the normative framework. The third component involves 'an enquiry into how to transform the what is into the what should be. This third component involving policy prescriptions is a very important feature and dimension of Islamic economics where the epistemological base of Islamic economics, founded on revelation, has a different implication with regards the relationship between theory and practice/ behavior of human beings (Haneef and Furqani, 2011).

Finally, from the above explanation we can conclude that to Islamize economics there is not a way except we should conduct critical engagement to modern economics because the economics today is not value-free nor is it ideology-free. Most of social sciences are taught includes economics were built from the 'structure of foundations' that represent western ideology (al-Attas, 1978). As a normative frame work, western ideology has a certain value in seeing man behavior as an object study of economics. Islam, on the other hand, seeing the human being and their relationship to other human beings and their nature is different from the western way. Additionally, this view brings implication to us for making a critical evaluation to modern economics based our Islamic value; hence, we should strengthen our foundations. In strengthening our foundation we must focus on epistemological and methodological concern that requires 'some sort of integration of knowledge'.

It needs to 'master' both the heritage and modern economics (critically) and then make creative synthesis/integration. After talking the normative area, Islamization has to answer the actual human behavior or we call positive economics, therefore, we need interaction with modern economics to make integration with the our heritage. In this phase, we must know which parts in modern economics to eliminate or reject and why we do so. Developing Islamic alternatives must be attempted to solve the problems of the individual, ummah and humanity at large. The last, we must try to implement our Islamic economics in policy to be evaluated whatever it give more beneficial or not, and how the effectiveness the Islamic policy in solving the problem of ummah.

\section{METHODOLOGY OF ISLAMIC ECONOMICS}

According to the article, Islamic economics is defined as an authority that has specific purposes and makes human being close to God our creator and considered as a rational practice to work out the economic problems (Tahir, 2013). Tahir argues that it is important to mention that the Islamic economic model is related to three goals: one is to make out the model in different areas of life and secondly is to maintain the achievement of the model itself and finally is to contribute of finding solutions to the existing faced difficulties by doing diagnostics and analysis based on Qur'an and the Sunnah. In addition with new scholarly efforts and intellectual integrity "Ijtihad" in the Micro and Macro levels and also finding routes to deal with non-Muslim economic models.

On the other hand, assumptions of the model and analysis should lead to good research with good outcomes that have feed backs at each stage, from the beginning to the interpretation of the results; in order to recognize the most suitable hypothesis that determine the function of an mechanism such as "the Breton Woods" monetary system as example. Or to study the behavior of an agent, a consumer in the market according to the context of Islamic economy. Furthermore, the empirical study provides the necessary explanation of the ideas by using a range of mathematical and statistical information that help to understand more cases.

In this context of methodology, a pertinent question appears? How to distinguish and differentiate between Islamic Economic Model's methodology with other kind of methodologies like the Islamic jurisprudence "al-Fiqh" and the conventional economic model? The Islamic economic model is concerned with the instrumental concept of the individual and institutional behavior in the context of permission, recommendation or prohibition. Otherwise, the fiqh is more concentrate on doing or not doing and providing new structures of adaptation to new environment according to the fives axioms of 


\section{Review Of Theoretical And Empirical Research In Islamic Economics}

Islamic law "Maqasid al-Syari'ah" which is considered an appropriate tool to use in the Islamic economic methodology without following deeply the ways of fiqh, but also sequence with Qur'an and the Sunnah. Alternatively, the conventional model is based on describing, structuring tools and optimistic expectation, individualism and coexistences policies.

In order to get more reliable results, the researcher should be pragmatic, objective and have to use intellectual integrity "Ijtihad" as it is used in the other methodologies -Islamic law or conventional economics- to solve the existing problem that all humanity is concerned about not only for Muslims but also for Non-Muslim under universal values and one living globe.

\section{THE ORETICAL RESEARCH IN ISLAMIC ECONOMICS}

From the beginning of Islam, Islamic economics has been subsisted up to our days. One of the most important theoretical works in the field made by Ibn Khaldun in the $14^{\text {th }}$ century. It is founded on intense annotations and directed to uncovering organized models that are useful in our daily life and also related to the origins and sources of one phenomenon with its consequence associations. Contemporarily, theoretical researches about the Islamic economics have been exposed since the last quarter of the $20^{\text {th }}$ Century and make it in appearance and the surface of the studies. The coming out and need of Islamic Finance helped a lot in multiplying the efforts on the field.

As a result, modern Islamic scholars tried to conduct new theories and academic researches to perform the best model for an Islamic economic system in different aspects deliberated in accordance with the Qur'an and the Sunnah: The transactions norms, market function and structure, type of economic institutions.

The need of more clearance in some area and hypothesis, and applying conventional economic principals into the Islamic model creates confusion. That should be avoided by excluding the nonIslamic economics criteria that exists in the conventional model with the addition of Islamic values. The process of Islamization of economics for developing an Islamic economics takes some dangers. The raison for that is the dissimilarity and unfeasibility of transplanting methods from conventional economics into Islamic economics. A good methodology would be to try to rebuild the Islamic economics in the context of actual perceptions in which suggested solutions fit the development of the models that are in line with Sharia.

In this situation it is preferable to show a brief case of Naqvi (1979) who used the "equilibrium" term to clarify the term "al-meezan" or balance in Islamic perspective. In fact, equilibrium has different meaning in the economical context. It shows a condition that the modification of the based variables of a model has not an intrinsic tendency, which goes far away from the Islamic concept of al-meezan. It is useful to state that the techniques of conventional economics and the terms in different situations need more care and caution (Tahir, 2013).

\section{Empirical Research In Islamic Economics:}

Research on the scope of empirical studies in Islamic economics and their purposes are very rare and in some cases are mentioned indirectly.

According to Tahir (2013) scope of empirical research in Islamic economics can be in three forms, compilation of data and statistical analysis, empirical analysis involving application of econometric and non-parametric methods, and the third form is simulation.

During the past fourteen centuries, there has been historical records of the Muslim societies which can be translated into data. For instance, income and expenditure data are available in some Muslim countries on a regular basis. Thus, analyzing poverty and income inequality could be possible. The government may do surveys to develop data sets on Zakat and Awqaf. Such efforts will help the government to construct its welfare policy. Those data can also be used for empirical studies by Islamic economists. Islamic economics will face the problem of data for testing theoretical propositions. Thus simulation option may be exercised.

Tahir (2013) states that there are three purposes of empirical research in Islamic economics which are: validation of theoretical propositions, evaluation of relative performance of an Islamic economy on the criteria of efficiency, equity or stability and probing ground realities in non-Islamic setups from the Islamic angle. 


\section{Review Of Theoretical And Empirical Research In Islamic Economics}

As far as validation is concerned, the theoretical propositions may be working hypotheses serving as input for theoretical constructs or descriptive models. Empirical work in terms of evaluation is already underway in the field of Islamic banking and finance. As for probing, Islamic economists may empirically study negative implications of modern day dichotomy between financial and real sectors in an economy in order to build support for Islamic financial architecture.

In their research, the statistical analysis of the research characteristics in Islamic economics, Saeed et al(2008), found that the descriptive analysis studies represent $69 \%$, while descriptive statistics and econometric analysis in islamic economics represent only $6.1 \%$ and $4.1 \%$ respectively. In other words, empirical researches in Islamic economics are estimated to be $10.2 \%$ only.

The same issue was risen by siddiqi (2008), in which considers the lack of empirical studies as one of the Islamic economic obstacles. There is a lot of theoretical studies on what a Muslim individual or institution should be done. But is their behaviors compatible with what they should do?. Thus being informed about the real Muslim individual and institution ( such as zakah and awqaf) behavior can help for addressing it, if it is different from what it should be.

In a nutshell, more empirical researches are needed in the field of Islamic economic in order to accept or falsify theories and models suggested by the Muslim researchers, in order to respond more appropriately to the situation, to provide respect to contextual differences and help to build upon what is already known.

\section{CONCLUSION}

Islamization of economics that has been done since 1970s and until now we are still doing the process of Islamization, actually needs our hard effort to master booth the modern economics frame work and our heritage. On the other hand, the contemporary Islamic economics must be supported with the foundational areas such as methodology based on Islamic world view, in this respect economists must pay more attention on philosophy, epistemology its Islamic Economics. Again, in developing alternative economics, it is important to look at the 'foundations' of neoclassical economics as mainstream school today and give criticism to their foundations in order to expose our Islamic teaching regarding to make our Islamic economics to become more exist.

Furthermore, as a discipline, focus should move to discussing usul al-iqtishad that would involve a much wider scope of subjects covering worldview, philosophy especially epistemology, methodology of Islamic economics and other social/human sciences. If we are determined to develop a sustainable alternative to western economics, the present writer does not see how it would be rational for us to continue to neglect this area. We must be willing to take bold measures and introduce curriculum reform in our Islamic economics programmes. We must also be willing to ask the right questions when it comes to the practice of economics, especially in the areas of banking and finance and not necessarily allow financial considerations to determine the direction of discipline.

Nowadays, it is very known in the economic vocation that economic science-as one of the social sciences- is inseparable from other areas of social studies. Therefore it is recommended that toleration of certain of ideological and religious ideas is not harmful to the sake of the knowledge for both readers and theoreticians. Also it is proved that one-sided approach or point of view, gives only the examination of that one side of the demonstration without looking objectively to the others. The need for a holistic loom to study economics seems to be very important in this case, which is already a character of the contemporary Islamic economic model and thought with the new form.

Researchers, should give more attention to empirical studies, in order to check the issue of "what is" and "what should be" in Islamic economics. In other word the issue of perceived ideals and versus factual realities in Muslim societies. 


\section{BIBLIOGRAPHY}

Ahmed Saeed Bamakhramah and Mohammed Omar Batwaih, Statistical Analysis of Characteristics of Research on Islamic Economic, Seventh International Conference on Islamic Economics, Islamic Economics Research Center, KAAU, Jeddah, April 1-3,2008

Aslam Haneef, Comment on Obstacles to Islamic Economics Research, Seventh International Conference on Islamic Economics, Islamic Economics Research Center, KAAU, Jeddah, April 1-3,2008

Hafas Furqani and Mohamed Aslam Haneef, Theory appraisal in Islamic economic methodology: purposes and criteria, Humanomics Vol. 28 No. 4,2012 pp. 270-284 Emerald Group accessed on: www.emeraldinsight.com/0828-8666.htm

Monzer Kahf, Islamic Economics: Notes on Definition and Methodology Review of Islamic Economics, No. 13, 2003, pp. 23-47

Mohamed Aslam Haneef, A Critical Survey of Islamization of Knowledge, 2nd Edition. Kuala Lumpur: International Islamic University Malaysia, 2009.

Mohamed Aslam Haneef and Hafas Furqani, Contemporary Islamic Economics: The Missing Dimension of Genuine Islamization, Thoughts on Economics Vol. 19, No. 04

Muhammad Akram Khan, Methodology of Islamic Economics Journal of Islamic Economics, Vol 1 $\mathrm{N}^{\circ}$ 1,Muharram $1408 \mathrm{H} /$ Aug-Sept 1987

Muhammad Anas Zarqa, Islamization of Economics: The Concept and Methodology J.KAU: Islamic Econ., Vol. 16, No. 1, pp. 3-42 (1424 A.H / 2003 A.D)Kuwait

Mohammad Nejatullah Siddiqi, OBSTACLES TO ISLAMIC ECONOMICS RESEARCH, Seventh International Conference on Islamic Economics, Islamic Economics Research Center, KAAU, Jeddah, April 1-3,2008

Nor Wan Daud, The Concept of Knowledge in Islam, London, 1989. As quoted by Mohamded Aslam Mohamad Haneef in Islam, The Islamic Worldview, and Islamic Economic, IIUM Journal of Economics and Management 5 No. 1,1997

Syeed Muhammad Naquib al-Attas, Islam and Secularism, Istac, KUalalumpur, 1978

Waleed A.J. Addas, Methodology of Economics: Secular Versus Islamic, International Islamic university Malaysia (IIUM) Press First edition, 15. January 2008 Online at http://mpra.ub.unimuenchen.de/8264/ MPRA Paper No. 8264, posted 5. May 2008 13:49 UTC. 